Editorial

\title{
Access to Higher Education: An Instrument for Fair Societies?
}

\author{
Gaële Goastellec ${ }^{1, *}$ and Jussi Välimaa ${ }^{2}$ \\ ${ }^{1}$ LACCUS, OSPS, LIVES, Institute of Social Sciences, University of Lausanne, 1005 Lausanne, Switzerland; \\ E-Mail: gaele.goastellec@unil.ch \\ ${ }^{2}$ Finnish Institute for Educational Research, University of Jyväskylä, 40014 Jyväskylä, Finland; E-Mail: jussi.p.valimaa@jyu.fi \\ * Corresponding author
}

Submitted: 23 November 2018 | Published: 10 January 2019

\begin{abstract}
Access to higher education (HE) has a long history. To offer a view on the current debates and worldwide issues regarding access to $\mathrm{HE}$, this editorial depicts how the control of educational access has historically been used as an instrument of governance at the interface of two processes: social stratification and the territorialisation of politics. Access to $\mathrm{HE}$ has remained embedded in these large structural processes even though HE has expanded from a highly elitist institution into mass education systems with equity of educational opportunities having become a desirable goal across societies. Analysing these processes helps understand the complex mechanisms producing inequalities in HE today, which are brought together by the ten articles composing this special issue. Tacking stock of how inequalities in access are produced in different continents, countries, HE Institutions, applying to different social groups though evolving mechanisms, these articles document the importance of contrasting methodological and theoretical approaches to produce comprehensive knowledge on this sensitive issue for democratic societies.
\end{abstract}

\section{Keywords}

fair access; higher education; inequality; methodology; theory

\section{Issue}

This editorial is part of the issue "Inequalities in Access to Higher Education and Degrees: Methodological and Theoretical Issues" edited by Gaële Goastellec (University of Lausanne, Switzerland) and Jussi Välimaa (University of Jyväskylä, Finland).

(C) 2019 by the authors; licensee Cogitatio (Lisbon, Portugal). This article is licensed under a Creative Commons Attribution 4.0 International License (CC BY).

\section{Introduction}

Over the last century, inequality in access to higher education (HE) has become an important topic both for scholars and policymakers. However, the political interest for educational access goes further back. Whatever the period of time or a place considered, access to $\mathrm{HE}$, understood in the broad sense, appears to have been the core issue when defining the role of universities in society. How access and admission to HE have been organised represents a most important instrument of governance because it is in the interface between the processes of social stratification and of the territorialisation of politics. This interface is today still framing the production of inequalities in access to $\mathrm{HE}$, despite the spreading and commonly shared assumption that equity in access is a desirable goal. However, the definition of social justice varies between societies, as well as the national and institutional definitions related to its implementation and for which social groups it should be targeted.

What are the mechanisms behind inequalities in today's HE systems and how can they be measured and explained? The articles in this thematic issue propose answers nested in sociological, political science, historical comparative and ethnographic perspectives, covering a broad geographical scope with nine countries (Brazil, England, Finland, France, Germany, Ireland, Israel, South Africa and Switzerland) from four continents. 
2. Looking Back, Looking Forward: Educational Access as an Instrument between Social Structures and Political Territories, Social Characteristics and Citizenship Categories

The organisation of access to HE has a long history. Since the creation of the very first universities, access and admission processes to universities, degrees, and the academic profession have been at the core of negotiations between universities' internal actors and external political powers at different levels of territories. The access issue included the geography of higher education institutions (HEls) as well as the territorial and social perimeter of their recruitment, an issue deeply embedded with the definition of the privileges and duties of university students, graduates and teachers, already topical in the Middle Ages and continuously relevant today.

The question of who have access, or who are admitted, is thus a recurring issue, variably addressed depending on HEls' contexts and periods of time but systematically traversed by a tension related to which groups of the social structure are accepted both by universities and by the rulers as well as their territory of action. Starting in the 12th century in Paris and Bologna, the creation of the first colleges alongside universities was aimed at providing accessibility for some less wealthy students, identified as potentially constituting the future administrative elite of the rulers of the territories they originated from.

Conversely, the exceptionality of access in some social groups a priori excluded from HE was made possible by their belonging to socio-economically advantaged groups. This was the case for women, for whom access was forbidden as stipulated in universities decrees, with exceptions being made over the centuries for some aristocrats mainly in Southern Europe (Goastellec, in press; Noble, 1992). The same was observed for a few "local" students in the context of the "colonies" where the university institution was exported. Belonging to local aristocracies enabled access to some forms of HE for the native population (Goastellec, 2010; Gonzalez \& Hsu, 2014), while access to colleges and universities was used to select those who will compose the future local elites, destined to work hand in hand with the local administration of the empire. These students often already belonged to the ruling group before the colonisation and became actors in the processes of independence.

Thus, historically, access to HE appears to be an instrument where social structures meet the territorialisation of politics, sustaining various political and societal projects. The selection of students, traditionally based on their social characteristics and the needs of the rulers to administrate their territories, account for the role of $\mathrm{HE}$ in social organisation and related schemes and processes. The link between the students' social characteristics and access to education runs across times and places through various configurations articulating the geographical, socio-economic, ethnic origin and gender of the potential students.
The student's social characteristics impinging on access to HE is akin to citizenship, in line with Bickel's notion that (1) citizenship "can exist without democracy...and relates to the rights and obligations associated with the citizen status, which can be decided and allocated by the rulers" and (2) it is a concept which "concentrates a complex stratification of multiple significations from various eras" (Bickel, 2007, pp. 12-14). The way the categories of citizenship impinge on educational access relates to the social organisations' variety of citizenship categories and rights associated with it applying both to its allocation to individuals born within the territory and to individuals coming from other social organisations.

For example, in 17th and 18th century Mexico, university degrees obtained by some nobles from the indigenous elite:

Indicated something more than mere education: they signalled honor, an invaluable (and inheritable) social quality.... This quality, which transcended ethnicity, partially exempted...native lords from colonial hierarchies that disadvantaged non-Spanish ancestries. (Villella, 2012, p. 12)

A university degree was a path to the imperial and ecclesiastical bureaucracy, to some professions with access usually restricted to those of Spanish descent. For some families, it sustained an entry into political positions of authority on both sides of society: local historical nobility and the Imperial state. In the same vein, in 19th- beginning of 20th-century Russia, citizenship and $\mathrm{HE}$ studies worked hand in hand. Here too, HE degrees paved the way to social positions backed by what could be called a better citizenship capital, entitling to some form of political participation. While in Russia this was one of the factors to prevent women from accessing the same HEls and degrees as men, in other countries, such as England or Portugal, it worked the other way around: HE degrees became a tool for women to achieve political citizenship, university graduates becoming the first women to gain access to the census suffrage in 1918 and 1931, respectively.

The diffusion of more inclusive political citizenship within democratic societies have not erased the issue, as asylum-seekers and refugees' difficulties to access HE today illustrate (Détourbe \& Goastellec, 2018). In all cases, historical and contemporary access policies, citizen rights and social identities are tied together.

\section{Access as a Tool for Fair Society: A Spreading Norm Variably Defined and Instrumented}

Yet, a paradigm shift occurred after the Second World War; it was characterised by the trend toward a broader access to education and by the spreading notion of promoting equal access for all social groups. Because $\mathrm{HE}$ studies and degrees come with many public and private benefits, it is widely admitted today that "[a]ny society 
committed to promoting equity must ensure that their education system, including their tertiary education sector, is accessible to students from the broadest spectrum of underrepresented and traditionally excluded groups" (Salmi \& Bassett, 2012, p. 3).

Since the Second World War, the question of social justice in access to HE has become a political and economic issue, with the aims of "mobilising the productive power of nations and realising a more acceptable social equity in the distribution of opportunity" (Halsey, 1993, p. 129). Accordingly, these two aims have been translated into the massification trend of HE. Access to HE was initially organised on the basis of academic merit-secondary degrees used as the main condition for admission - and later complemented by an increased diversity of admission processes considering a wider range of academic criteria as well as some social characteristics of the students.

HE systems have thus progressively, although at different rates and paths, shifted from being an exclusive good, reserved for a happy few (young men from the upper middle classes and bourgeoisie, capital cities and belonging to the ethnic majority), to being an inclusive good, accessible to women, lower middle and working classes, ethnic minorities and middle-size towns students (Goastellec, 2008). As a result, in 2014, the number of students enrolled in HE worldwide exceeded 200 million, having more than doubled since the beginning of the 21st century (UNESCO, 2016). However, important disparities exist between countries and continents with regard to the proportion of an age group accessing $\mathrm{HE}$ (the smallest access rates being observed in Africa) as well as regarding the characteristics of the student body. Differences continue to exist between men and women, but the sense of the variation differs between countries, with a few developing policies aimed at promoting men's access in contexts where they are now largely underrepresented, such as in Sweden or Norway (Santiago, Tremblay, Bari, \& Arnal, 2008).

However, in most countries, the probability of HE enrolment depends strongly on the family's wealth, which together with gender is probably the most widely examined factor, measured through various indicators such as income, profession or parental level of education. In addition, differences in enrolment rates related to other social categories are also meaningful, as illustrated by the inequalities observed between ethnic groups in South Africa by Melanie Walker (2019) in this special issue. There the probability for Afrikaners and Coloured people to participate in $\mathrm{HE}$ is less than a third of that of Whites or Indians (CHE, 2013). In Israel, Arab students are less represented than Jews, as discussed by Eyal Bar-Haim and Carmel Blank (2019). Furthermore, in highly stratified systems such as the UK, differences do not reside in access per se, as shown in O'Sullivan, Byrne, Robson and Winters (2019) in this thematic issue, but in the small number of under-represented groups in the most prestigious HEls in 2015. For instance, one third of Oxford colleges did not admit any black British students. As suggested by the comprehensive overview offered by the ten articles of this special issue, each country appears to lean towards the use of a specific set of statistical categories framing their access policies; categories that are nested in a specific history and are in part path-dependent.

At the dawn of the 21st century, equity in accessleaning toward a student body representative of the population structure in society-is becoming the norm. International organisations, as well as macro-regional institutions provide discursive incentives towards the measurement of such distance (Goastellec, 2008, 2010), with various foci: for example, the United Nations, with the fourth Sustainable Development Goal (SDG) and its target 4.3 , states that "by 2030 countries should provide equal access for all women and men to affordable and quality technical, vocational and $\mathrm{HE}$, including university" (UNESCO, 2016, p. 1). Such goals can also be found in some national constitutions (such as in Brazil) or in individual $\mathrm{HE}$ access policies and admission processes.

The diffusion of a shared norm questions its operationalisation: the issue of equal educational opportunities is a political one concerning the measurement of inequalities as well as the social diversity which can legitimately be measured. This dimension translates into methodological debate with regard to the categories available and used by researchers in order to measure inequalities.

In their article, Siddiqui, Boliver and Gorard (2019) make the case for choosing the statistical categories by taking account how missing data blur the results obtained, thus addressing the limitation of self-reported characteristics of the family. As a result, admission policies targeting specific social groups depend upon the management of this issue. The organisation of educational access in each country results from "a "tacit" or "implicit" contract among the main stakeholders which emerged under particular, idiosyncratic historical and social conditions" (Meyer, St. John, Chankseliani, \& Uribe, 2013, p. 2).

Who is expected in HE and who gets access to HE tell a lot about the place allocated to HEls in the social organisation and, more broadly, about the social organisation in which $\mathrm{HE}$ is embedded, its referential and social project. Access to HE contributes both to the reproduction of social structures/organisations and their transformation. Access can be comprehended as an instrument of government and, more precisely when it comes to the last centuries, as an instrument of public action aimed at sustaining a societal project. As the articles of this thematic issue demonstrate, we observe major national variants, which illustrate the relation between fairness and sovereignty.

The assumption behind the massification of HE was that it reduces inequalities because more students have access to HE. And indeed, massification comes with increased inclusion: the more individuals enter $\mathrm{HE}$, the more there will be degrees and members in the academic profession. When the HE sector trains elites and into elite, it 
can provide a large added value to degree holders. However, when large numbers of people are holding HE degrees, lacking a degree may become a strong handicap in the labour market. In addition, massification also tends to be accompanied with persistent inequalities within $\mathrm{HE} \mathrm{sec-}$ tors, protecting the historical advantages of a happy few.

Balbachevsky, Sampaio and de Andrade (2019) show that access has opened up so that in 2014 slightly more than $20 \%$ of the $18-24$-year-olds entered HE. However, expanding access to $\mathrm{HE}$ is not enough to reduce social inequalities. It now takes place through the development of the private sector and leads to the preservation of old hierarchies and thus supports structures of inequalities through a diversion process. The same can be observed in High Participation Systems (HPS) of HE (Cantwell, Marginson, \& Smolentseva, 2018) which are facing increasing institutional stratification with elite universities selecting students mainly from the highest social strata. In an HPS area, how are social inequalities in access to $\mathrm{HE}$ and its degrees measured, explained and theorised? Which are the various approaches dealing with this issue?

Researchers have focused on the structural dimension of education, discussing the degree of massification for previous levels of schooling such as the Maximally Maintained Inequalities (MMI) approach (Raftery \& Hout, 1993) or the EMI, Equally Maintained Inequalities (Lucas, 2001), or on the structure of secondary education (Goastellec \& Välimaa, 2017). Others have examined the choices made by students, analysing the educational paths followed and investigating the educational choices (Pilote, Picard, Goastellec, Turcotte, \& Olympio, 2015). While other streams of research have questioned the effect of governing political parties (Jungblut, 2014), welfare states (e.g., Pechar \& Andres, 2011; Peter, Edgerton, \& Roberts, 2010) and the trade-off between educational policies and other social policies (Busemeyer \& Nikolai, 2010), the hold of degrees on employment, or more broadly the effect of admission criteria (Childs, Ferguson, Herbert, Broad, \& Zhang, 2016), institutional and national policies and educational markets.

Canisius Kamanzi (2019) illustrates this process by analysing the interaction between students' social origin and public policies according to the conception and organisation of school market, showing that this interaction is linked to society at large, especially the way public policies in education interact with social actors. Although most Western HE systems have been massified for a few decades already, inequalities seem to persist. They also transform, becoming more qualitative, through a diversion process and emerging issues in some countries, such as refugees' access to $\mathrm{HE}$ (see, e.g., Breanne, Nawyn, \& Okwako, 2017; Dryden-Peterson, 2010; Jungblut \& Pietliewicz, 2017), which is analysed through an ethnographic comparative research by Katrin Sontag (2019). Her study shows how the student biography and migration history interact with how the asylum system, the educational one as well as the funding possibilities articulate, variably in each country.
Access to HE is multifaceted because it includes the provision of study places (HEls and their geography, the educational system HEls are embedded in), student' influx patterns and students' characteristics. Admission refers to processes sustaining or restraining students' access on the basis of a variety of criteria (social, economic, academic) and procedures (former degrees, exams, tests, ability to testify one's social position and, more broadly, one's social characteristics). Admission processes thus play a crucial role in organising the access and defining who actually enter HE. The instrumental role of access is thus even more clearly illustrated by research focusing on admission processes, with regard to the respective strategies of HEls and families. Indeed, the norm of inclusion is variously adapted depending on HEls, as illustrated by Mergner, Leišytè and Bosse (2019). Using a translation perspective, they show how universities translate political demands to their local context, underlining the importance of the HEl's identity as well as the actors involved (administrations or professors) and the discipline concerned.

O'Sullivan et al. (2019) also show in their article that when specific admission processes are dedicated to widening the student body, they attract different student profiles depending on how they are organised and, to some extent, on who is in charge of admission within a specific institutional culture. Interestingly, England and Ireland do not only differ by the admission processes implemented but also by who is responsible for identifying the student potentially benefiting from widening admission processes: HEls in Ireland, within a national frame, but students in England, where one must "opt in" to be considered, within an HEl's frame. Additionally, the diversion process observed at the HE systems level is also ongoing at the admission process: Bar-Haim and Blank (2019) again reveal that the population who benefits from second-chance admission processes is not the one targeted. Studying contemporary Israel in quantitative terms they show that the interest is usually directed to mainstream access, and students from the majority social group (Israeli) benefit more from second chance alternatives by comparison with Arab students, which leads to increased inequalities. At a policy level this also suggests the importance of temporally limited admission policies to limit family diversion strategies.

Conversely to these strategies of access developed by students from a non-targeted group, Walker (2019), in an insightful article studying the construction of access to HE through the choices of school paths and orientation, using the capability framework developed by Amartya Sen, shows that if the role of good schooling emerges as crucial, it is in the intersection with supportive family conditions that it works as a multiplier effect.

Inequalities do not disappear at later stages of university education or career: two articles discuss the longlasting effect of social characteristics in HE by investigating the profile of professors in HPS with regard to social origin and gender by comparing the profile of stu- 
dents and professors at different stages of educational and academic careers. Based on the Finnish case, Helin, Koerselman, Nokkala, Tohmo and Viinikainen (2019) offer a methodological contribution by documenting the importance of effective longitudinal studies to understand transitions in academic careers. By doing so, they also underline that different types of inequalities are structured through different processes, socio-economic inequalities taking the form of a leaky pipeline, while gender inequalities are doubled by a delay effect, women accessing the highest positions at an older age. Equally adopting a longitudinal approach with a social closure perspective, Blome, Möller and Böning (2019) defend the idea that inequalities related to social origin in access to academic careers are the product of intentional patterns of action aimed at securing the power of a specific group. Indeed, looking at the social origin of professors in Germany in comparison to that of students, they show the reverse trends of respective closing and opening.

\section{Conclusion: Educational Access as an Instrument of Fair Societies (If They Wish)}

The contrasted and complementary research presented in this thematic issue reminds that HE represents an important instrument to improve the fairness of societies. Not only for a fairer access to education but also for knowledge and jobs, increased social mobility, reduced social reproduction, etc. As these articles point out, the definitions of fairness vary between societies, and are differently translated depending on HE structures, HEI identities and the involved actors within this sector. Additionally, access as an instrument is both path-dependent and embedded in multiple structures and changing processes. Moreover, the actors, uses and users of access and admission processes change over time. This has consequences for both research and policies: because these processes are multidimensional, they can only be comprehended through bringing together multiple research approaches. In addition, because the processes producing inequalities evolve continuously, access issues should be studied and monitored on a regular basis in order to update the analysis and to understand the adaptation of educational access as a democracy instrument.

\section{Conflict of Interests}

The authors declare no conflict of interests.

\section{References}

Balbachevsky, E., Sampaio, H., \& de Andrade, C. Y. (2019). Expanding access to higher education and its (limited) consequences for social inclusion: The Brazilian experience. Social Inclusion, 7(1), 7-17.

Bar-Haim, E., \& Blank, C. (2019). Second-chance alternatives and maintained inequality in access to higher education in Israel. Social Inclusion, 7(1), 28-37.
Bickel, J. (2007). Significations, histoire et renouvellement de la citoyenneté [Significations, history and renewal of citizenship]. Gérontologie et société, 30(1), 11-28.

Blome, F., Möller, C., \& Böning, A. (2019). Open house? Class-specific career opportunities within German universities. Social Inclusion, 7(1), 101-110.

Breanne, L. G., Nawyn, S. J., \& Okwako, B. (2017). The right to belong (if you can afford it): Market-based restrictions on social citizenship in refugee resettlement. Journal of Refugee Study, 31(1), 42-62.

Busemeyer, M. R., \& Nikola, I. R. (2010). “Education”. In H. Obinger, C. Pierson, F. G. Castles, S. Leibfried, \& J. Lewis (Eds.), The Oxford handbook of the welfare state (pp. 494-508). Oxford: Oxford University Press.

Cantwell, B., Marginson, S., \& Smolentseva, A. (Eds.). (2018). High participation systems of higher education. Oxford: Oxford University Press.

CHE. (2013). 2013 higher education data: Participation. Council on Higher Education South Africa. Retrieved from www.che.ac.za/focus_areas/higher_ education_data/2013/participation\#race

Childs, R. A., Ferguson, A. K., Herbert, M. B., Broad, K., \& Zhang, J. (2016). Evaluating admission criteria effects for underrepresented groups. Higher Education Research and Development, 35, 658-668.

Détourbe, M. A., \& Goastellec, G. (2018). Revisiting the issues of access to higher education and social stratification through the case of refugees: A comparative study of spaces of opportunity for refugee students in Germany and England. Social Sciences, 7(10). https://doi.org/10.3390/socsci7100186

Dryden-Peterson, S. (2010). The politics of higher education for refugees in a global movement for primary education. Refuge, 27(2), 10-18.

Goastellec, G. (2008). Globalization and implementation of an equity norm in higher education. Peabody Journal of Education, 83(1), 71-85.

Goastellec, G. (2010). Small world: Access to higher education between methodological nationalism and international organisations. Globalisation, Societies and Education, 8(2), 283-293.

Goastellec, G. (in press). L'accès à l'Université enjeu de l'organisation sociale. Quelques apports d'une comparaison socio-historique [Access to university as an issue of social organisations: Contributions from a socio-historical comparison]. Sociologies. Manuscript submitted for publication.

Goastellec, G., \& Välimaa, J. (2017). Expliquer les inégalités d'accès aux diplômes en Finlande et en Suisse (1950-2004): Des structures scolaires aux politiques sociales [Explaining inequalities in access to degrees in FInland and Switzerland (1950-2004): From school structures to social policies]. Education et Société, 38(2), 105-121.

Gonzalez, C., \& Hsu, F. (2014). Education and empire: Colonial universities in Mexico, India and the United States (Paper Series CSHE.7.14). University of California, Berkeley. 
Halsey, A. H. (1993). Trends in access and equity in higher education: Britain international perspective. Oxford Review of Education, 19(2), 129-140.

Helin, J., Koerselman, K., Nokkala, T., Tohmo, T., \& Viinikainen, J. (2019). Equal access to the top? Measuring selection into Finnish academia. Social Inclusion, 7(1), 90-100.

Jungblut, J. (2014). Partisan politics in higher education policies: How does the left-right divide of political parties matter in higher education policy in Western Europe? In G. Goastellec \& F. Picard (Eds.), Higher education and societies. A multiscale perspective (pp. 85-110). Rotterdam: Sense Publishers.

Jungblut, J., \& Pietliewicz, K. (Eds.). (2017). Refugees welcome? Recognition of qualifications held by refugees and access to higher education in Europe-Country analyses. Brussels: ESU.

Kamanzi, P. C. (2019). School market in Quebec and the reproduction of social inequalities in higher education. Social Inclusion, 7(1), 18-27.

Lucas, S. R. (2001). Effectively maintained inequality: Education transitions, track mobility, and social background. American Journal of Sociology, 106(6), 1642-1690.

Mergner, J., Leišytè, L., \& Bosse, E. (2019). The widening participation agenda in German higher education: Discourses and legitimizing strategies. Social Inclusion, 7(1), 61-70.

Meyer, H.-D., St. John, E. P., Chankseliani, M., \& Uribe, L. (2013). Fairness in access to higher education in a global perspective. Rotterdam: Sense Publishers.

Noble, D. (1992). A world without women. The Christian clerical culture of western science. New York, NY: A. Knopf.

O'Sullivan, K., Byrne, D., Robson, J., \& Winters, N. (2019). Who goes to college via access routes? A comparative study of widening participation admission in selective universities in Ireland and England. Social Inclusion, 7(1), 38-51.

Pechar, H., \& Andres, L. (2011). Higher education policies and welfare regimes: International comparative per- spectives. Higher Education Policy, 24(1), 25-52.

Peter, T., Edgerton, J. D., \& Roberts, L. W. (2010). Welfare regimes and educational inequality: A cross-national exploration. International studies in Sociology of Education, 2(3), 241-264.

Pilote, A., Picard, F., Goastellec, G., Turcotte, M., \& Olympio, N. (2015). Opérationnaliser la théorie de la justice sociale d'Amartya Sen au champ de l'orientation scolaire: Les apports d'une étude multicas qualitative et comparative. [Operationalising Amartya Sen social justice theory in educational orientation: Inputs from a qualitative and comparative multi-case study]. Mesure et évaluation en éducation, 37(3), 5-37.

Raftery, A., \& Hout, M. (1993). Maximally maintained inequality: Expansion, reform, and opportunity in Irish education 1921-1975. Sociology of Education, 66(1), 41-62.

Salmi, J., \& Bassett, R. M. (2012). Opportunities for all? The equity challenge in tertiary education. Paper presented at the Salzburg Global Seminar, Salzburg, Austria.

Santiago, P., Tremblay, K., Bari, E., \& Arnal, E. (2008). Tertiary education in the knowledge society. Special features: Equity, innovation, labour market and internationalisation (Vol. 2). Paris: OECD.

Siddiqui, N., Boliver, V., \& Gorard, S. (2019). Reliability of longitudinal social surveys of access to higher education: The case of next steps in England. Social Inclusion, 7(1), 80-89.

Sontag, K. (2019). Refugee students' access to three European universities: An ethnographic study. Social Inclusion, 7(1), 71-79.

UNESCO. (2016). Global Education Monitoring Report 2016, Education for People and Planet, creating sustainable futures for all. Paris, France: UNESCO.

Villella, P. B. (2012). Indian lords, Hispanic gentlemen: The Salazars of colonial Tlaxcala. The Americas, 69(1), $1-3$.

Walker, M. (2019). The achievement of university access: Conversion factors, capabilities and choices. Social Inclusion, 7(1), 52-60.

\section{About the Authors}

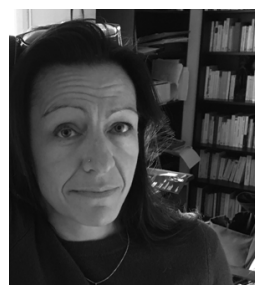

Gaële Goastellec is a Sociologist, Professor at the University of Lausanne, Switzerland. Her research interests lie in the comparison of higher education systems and the social organisations they are part of, with a focus on the socio-history of access to HE, as well as on academic careers. Amongst her last books publications is the International Encyclopedia of Higher Education Systems and Institutions (Springer, 2018, with P. Teixeira et al.) and L'envers du décor, Massification de l'enseignement supérieur et justice sociale (Presses de l'Université du Québec, 2017, with C. Kamanzi and F. Picard).

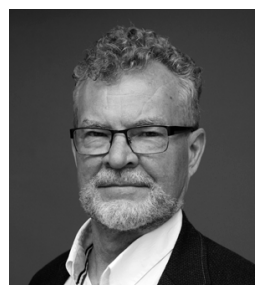

Jussi Välimaa is Professor in Educational Studies and Director of the Finnish Institute for Educational Research at the University of Jyväskylä, Finland. Being trained as an historian and a social scientist, Professor Välimaa has expertise in social and historical studies of higher education and education. His research profile is shaped by academic interest in the relationship between higher education and society. Professor Välimaa also has studied the internal dynamics of higher education institutions from cultural, historical and sociological perspectives. Professor Välimaa's latest book is A History of Finnish Higher Education from the Middle Ages to the Twenty-first Century (Springer, in press). 